\title{
Advection of continental water as an export mechanism for anchovy, Engraulis encrasicolus, larvae*
}

\author{
ANA SABATÉS, JORDI SALAT and M. PILAR OLIVAR \\ Institut de Ciències del Mar, CSIC, P. Joan de Borbó s/n, 08003 Barcelona, Spain. E-mail: anas@icm.csic.es
}

\begin{abstract}
SUMMARY: The presence of a surface layer of a less saline water of continental influence $(C I W)$ along the continental slope off the Catalan coast (NW Mediterranean) was observed in June 1995. This $C I W$ was formed in the Gulf of Lions from Rhône runoff and carried by the current associated with the shelf-slope front. This study analyses the spatio-temporal behaviour of that water of continental influence in relation to the shelf-slope front, and its effect on the distribution of fish larvae, in particular the larvae of the anchovy, Engraulis encrasicolus. Displacements of the front are observed to follow an oscillation with a period of eight days and an amplitude of $10 \mathrm{~km}$. Anchovy larvae were associated with the presence of $C I W$, whereas the oceanic species Hygophum benoiti appeared in the region of the slope when the front, and the associated CIW layer, moved close inshore during its oscillation. The size frequency distribution for the anchovy larvae trapped within the CIW suggests that the larvae had been spawned further north, near the Gulf of Lions. It is concluded not only that larvae were transported by the current but also that their development had taken place entirely inside the CIW. The possible benefit to the survival of anchovy larvae of being kept inside that water, though they have been carried far from their spawning areas, is discussed in the basis of fluorescence and microzooplankton data.
\end{abstract}

Key words: continental influence waters, shelf-slope front, transport, anchovy larvae, NW Mediterranean.

\section{INTRODUCTION}

The Catalan coast lies in the northwestern region of the Western Mediterranean Sea south of the Gulf of Lions. Input of continental water plays an important role in the region, especially from the outflow of the Rhône River, the largest river in the Western Mediterranean basin, which empties into the Gulf of Lions. In particular, the broad continental shelf off the Gulf of Lions (between 50 and $100 \mathrm{~km}$ ) acts as a holding area for waters with salinity levels normally between 1 and 2 psu lower than those in the open sea (Millot, 1990; Salat et al., 1990). Furthermore, by decreasing the salinity of inshore waters in the

\footnotetext{
*Received November 24, 2000. Accepted January 22, 2001.
}

region, the influxes of continental run-off help strengthen the structure of the shelf-slope density front associated with the Liguro-Provençal and Catalan Current (Font et al., 1988). This current is usually more than $300 \mathrm{~m}$ deep, with a flow rate of about $1 \mathrm{~Sv}\left(10^{6} \mathrm{~m} \mathrm{~s}^{-1}\right)$. Current velocity in the surface layer can easily reach $30 \mathrm{~cm} \mathrm{~s}^{-1}$ (Castellón et al., 1990).

Seasonal variability in the region affects not only the stratification of the water column but also fluctuations in continental run-off, hence its importance. In spring, a seasonal thermocline forms as the daylight lasts longer. At the same time, fresh-water input increases, not only because of high rainfall but also because of high flow rates in the Rhône River due to the spring thaw in the mountains. For these 
reasons, areas of low surface salinity water (below 37.5) are commonly found off the Catalan coast at the end of spring (Tintoré et al., 1990). Occasionally, these waters may even be much less saline than usual (below 35) as reported by Castellón et al., (1985). The presence of these waters of continental influence with relatively low salinity, hereinafter referred to as $C I W$, is enhanced by the combined action of low wind speed and increasing thermal stratification, which help to maintain the $C I W$ recognizable until the end of spring. The current flow associated with the front may help carry the $C I W$ along the shelf break, far from where they formed. The higher influx of continental run-off contributes to an increase in the mesoscale activity at the shelfslope front typical of the spring season (Alberrola et al., 1995; Font et al., 1995). In particular CIW were also found in filaments that move cross-wise to the general circulation pattern, flowing ageostrophically (Wang et al., 1988). Instabilities in the density front also give rise to fluctuations in the location and strength of the front (Alvarez et al., 1996).

The increased stratification taking place in spring also brings about gradual depletion of nutrients in the surface layer by restricting vertical water movements that could help to replenish the nutrient levels. Thus, by the end of spring phytoplankton populations have practically disappeared from the entire surface layer and are concentrated beneath the thermocline, producing what is known as the deep chlorophyll maximum (Estrada, 1985; Estrada and Salat, 1989). However, since the continental run-off is rich in nutrients, the areas occupied by the $C I W$ may afford suitable conditions for the development of phytoplankton populations in the surface layer.

The general distribution pattern for fish larvae along the Catalan coast exhibits an increase both in the number of species and in the number of individuals from nearshore towards the open sea. Peak larval concentrations occur over the edge of the continental shelf in the vicinity of the shelf-slope front as a consequence of the combined presence of inshore and oceanic species (Sabatés, 1990a). Nevertheless, significant deviations from that general pattern may be observed in spring. The inputs of CIW and the substantial mesoscale activity generally recorded during spring contribute to a considerable increase in spatial heterogeneity in the distribution of fish larvae (e.g. Sabatés, 1990b; Sabatés and Masó, 1992; Olivar et al., 1998).

The anchovy is one of the most common pelagic fish species dwelling over the shelf in the region.
This species' spawning peak takes place at the end of spring, coinciding with the time when continental run-off in the surface layer reaches its maximum extent. Therefore, high egg and larval abundance for anchovy is often clearly associated with areas of fresh water input (Palomera, 1992). Furthermore, salinity values for such waters have sometimes been unusually low (30), with anchovy being the only species present in the ichthyoplankton in those waters (Sabatés, 1990b).

In recent years a series of studies have been carried out in the Catalan Sea in order to improve our understanding of both the hydrographic dynamics contributing to the mesoscale variability within the front and the response of ichthyoplanktonic populations to this dynamics. A study based on short (10 day) sampling intervals conducted in spring 1992 provided significant results. High temporal variability in mesoscale structures was observed (Alvarez et al., 1996), along with the response of larval fish populations to that mesoscale activity (Sabatés and Olivar, 1996; Masó et al., 1998). The 10-day interval between surveys turned out to be too long in terms of the time scale of mesoscale structures. According to these results, subsequent monitoring required a finer temporal scale in order to fully record mesoscale variability. In June 1995 a study of the mesoscale variability in the Catalan Sea was performed with an adequate spatio-temporal scale.

In this paper we analyse the temporal and spatial mesoscale variability found in the June 1995 study, and the effects of this variability on the distribution of the larvae of certain fish species. In particular, we examine the behaviour of a $C I W$ layer running along the edge of the continental shelf and the reproductive strategy of the anchovy, Engraulis encrasicolus, to take advantage of the existence of this structure.

\section{MATERIAL AND METHODS}

The study was carried out in the Catalan Sea (Western Mediterranean Sea) in June 1995. Three oceanographic cruises were conducted, two concurrently, employing different sampling strategies and covering different areas within the region (Fig. 1):

a) Mesoescala ' 95 survey, hereinafter referred to as the first cruise. This survey was carried out by the R/S García del Cid from 31 May to 17 June. It covered a large area in the southern half of the Catalan Sea. Sampling stations were located between 15 and $22 \mathrm{~km}$ apart, along transects perpendicular to the 


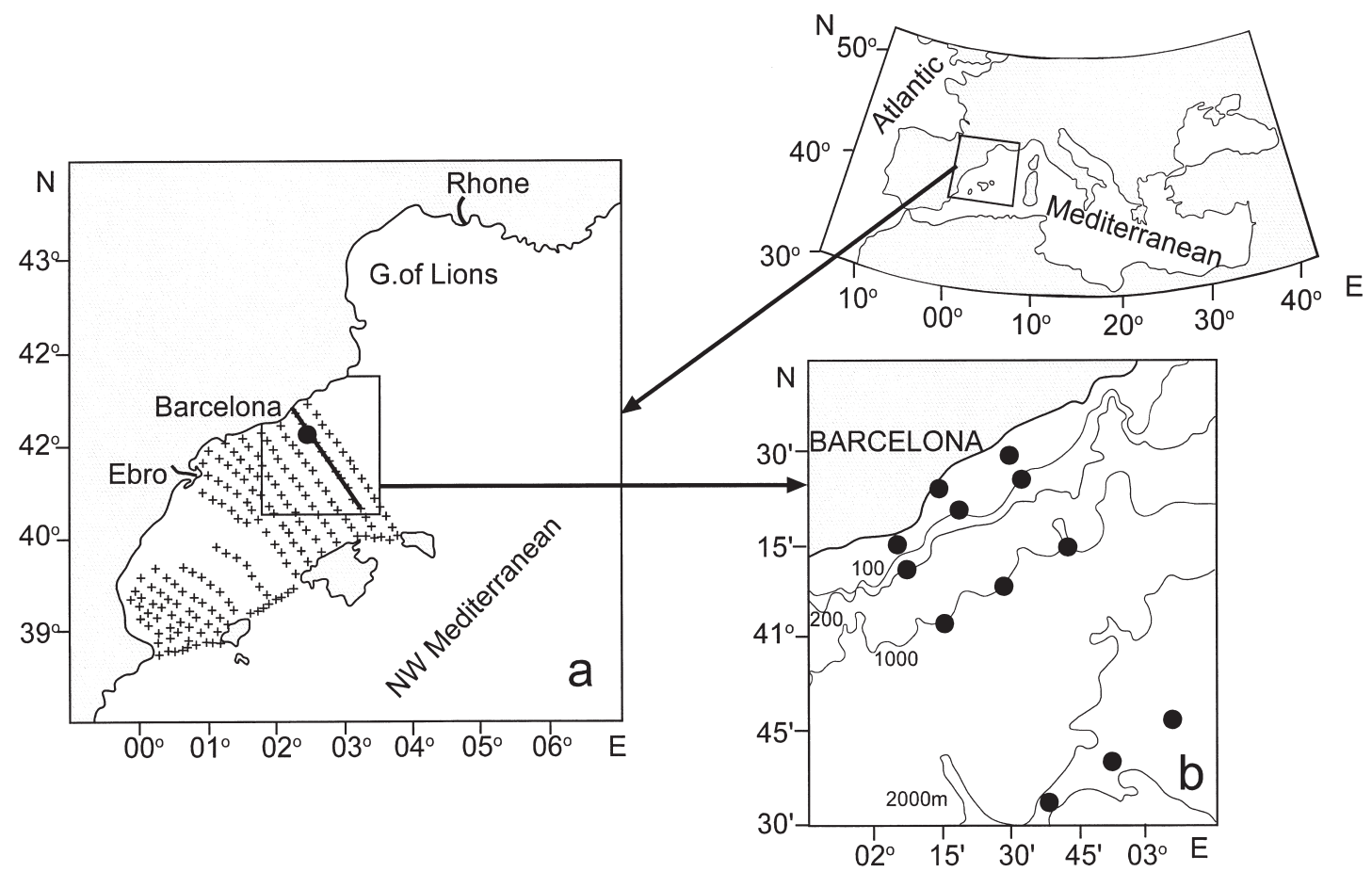

FIG. 1. - Map of the study area showing the main sampling grids during the three oceanographic surveys. (a) Station grid sampled on the Mesoescala '95 survey; the solid line indicates the transect revisited on the Varimed ' 95 survey, and the circle shows the station over the slope where three 24-h sampling periods were performed. (b) Station grid sampled on the Fronts ' 95 survey.

coastline (Fig. 1a). Vertical profiles of temperature, salinity and fluorescence were obtained at each station using a Neil Brown Mark III CTD.

b) Varimed ' 95 survey, hereinafter referred to as the second cruise. This survey was carried out by the $\mathrm{R} / \mathrm{S}$ Hespérides from 2 to 14 June. Sampling stations were located along a single across-shore transect off Barcelona (Fig. 1a). The location of this transect was the same as the one done during the previous cruise on 31 May. The transect was visited twice, on 6 and 10 June, and sampling included the collection of CTD data. Additionally, three 24 hour sampling cycles (June 4, 8 and 12) were done at one station located over the slope where the bottom depth was $1000 \mathrm{~m}$ (Fig. 1a), in order to assess the variation of the physical parameters over a daily cycle. During the 24-hour cycles CTD casts were repeated at roughly 4 to 5 hour intervals.

c) Fronts ' 95 survey, hereinafter referred to as the third cruise. At the end of the first cruise, R/S García del Cid carried out a local study of spatiotemporal variability in mesoscale structures off Barcelona. From 18 to 23 June a series of stations were visited along three transects, running perpendicular to the coast, $22 \mathrm{~km}$ apart. Four stations were located on each transect, over bottom depths of about $40 \mathrm{~m}$ near the coast, $70-80 \mathrm{~m}$ over the shelf, $1000 \mathrm{~m}$ over the slope, and more than 2000 $\mathrm{m}$ in the open sea (Fig. 1b). The position of the station over the slope on the central transect was the same as that for the station at which the 24-hour sampling cycles were performed during the second cruise. It took about three days to sample the entire grid and all stations were visited at least twice over the course of one week. Surface temperature and salinity were continuously monitored in real-time throughout the entire cruise using an SBE-21 thermosalinograph. As on the other cruises, CTD profiles were compiled at each station. Copepod nauplii were collected by means of vertical hauls from $40 \mathrm{~m}$ depth to the sea surface using a net with an opening of $40 \mathrm{~cm}$ in diameter and a mesh size of 53 $\mu \mathrm{m}$, equipped with a flowmeter. Two aliquots were taken from each sample, and at least 100 individuals in each aliquot were counted. Mean concentration in the aliquots was expressed as number of individuals per $\mathrm{m}^{3}$. Fish larvae were sampled by means of oblique tows using a Bongo net with an opening of $60 \mathrm{~cm}$ in diameter and a mesh size of $500 \mu \mathrm{m}$, from a maximum depth of $200 \mathrm{~m}$ to the sea surface. The volume of water passing through the meshes was estimated using a flowmeter. Since these tows sampled the entire water column, the number of larvae collected at each station was standardised to the number of individuals per $10 \mathrm{~m}^{2}$ of sea surface. 


\section{RESULTS}

\section{Hydrography}

The general coverage provided by the first cruise showed that both the shelf-slope front and the associated geostrophic current were well established along the shelf break off the Catalan coast (Fig. 2). On the southern side of this map appears the North Balearic front (Pinot et al., 1994) separating low salinity water of recent Atlantic origin $(A W)$ from the water of the center of the basin. The presence of lower salinity $A W$ at surface is also evident on the right side of the vertical sections (Fig. 3). Throughout this paper, however, we do not deal
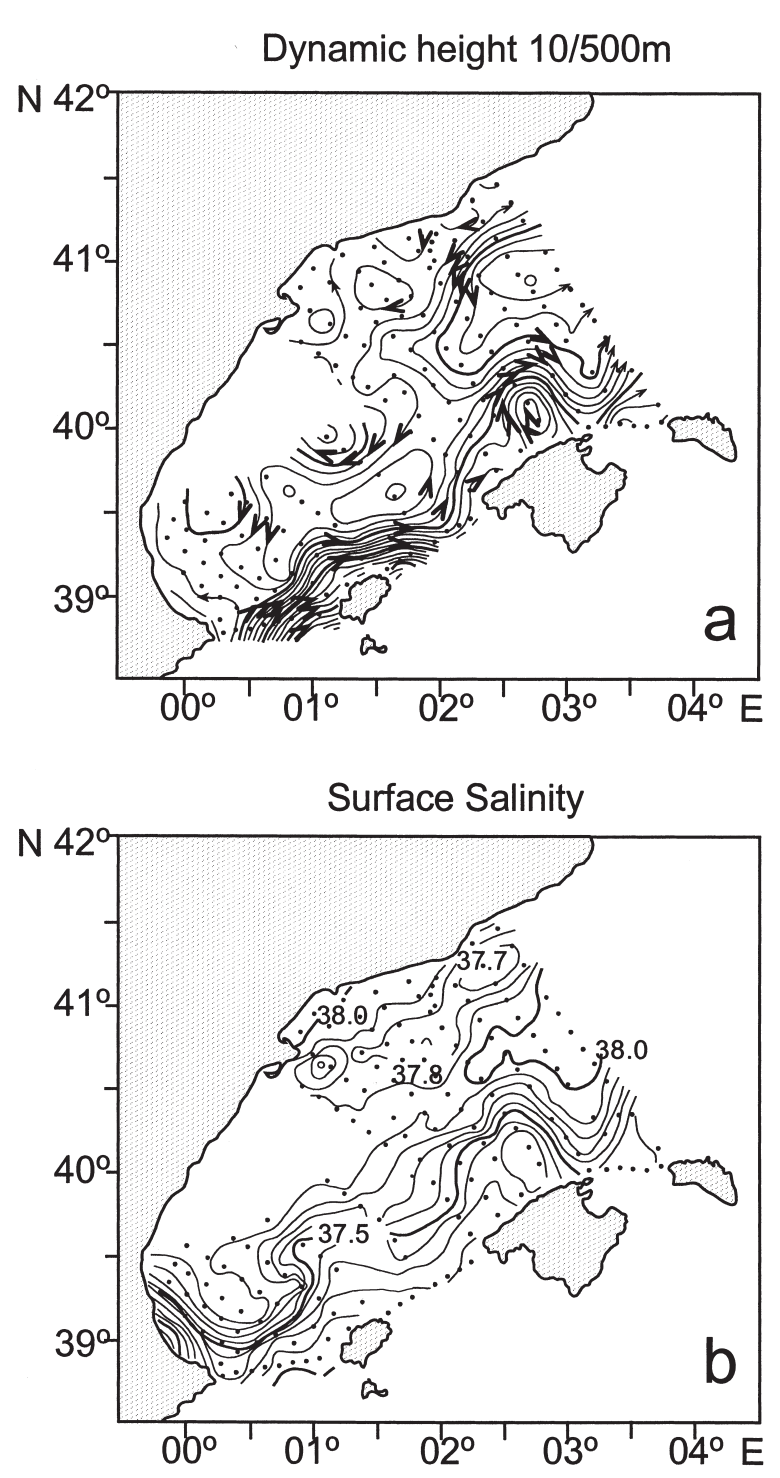

FIG. 2. - Mesoescala '95 survey: a) dynamic height at $10 \mathrm{~m}$ taking $500 \mathrm{~m}$ as the reference level, and b) surface salinity distribution. either with the North Balearic front or its associated current and water.

The horizontal density gradients of the shelfslope front along the Catalan coast were significant in the entire mass of slope water down to at least 300 $\mathrm{m}$ depth (Fig. 3). Maximum current speed off Barcelona was more than $30 \mathrm{~cm} \mathrm{~s}^{-1}$, and the velocity exceeded $20 \mathrm{~cm} \mathrm{~s}^{-1}$ across a broad band about 15 $\mathrm{km}$ wide extending down to a depth of about $60 \mathrm{~m}$. Water transport associated with this current was of the order of $1 \mathrm{~Sv}\left(10^{6} \mathrm{~m} \mathrm{~s}^{-1}\right)$. The seasonal thermocline was in the process of full development, typical of the end of spring. The maximum vertical temperature gradient was located at depths of between 30 and $50 \mathrm{~m}$. The position of the shelf-slope front
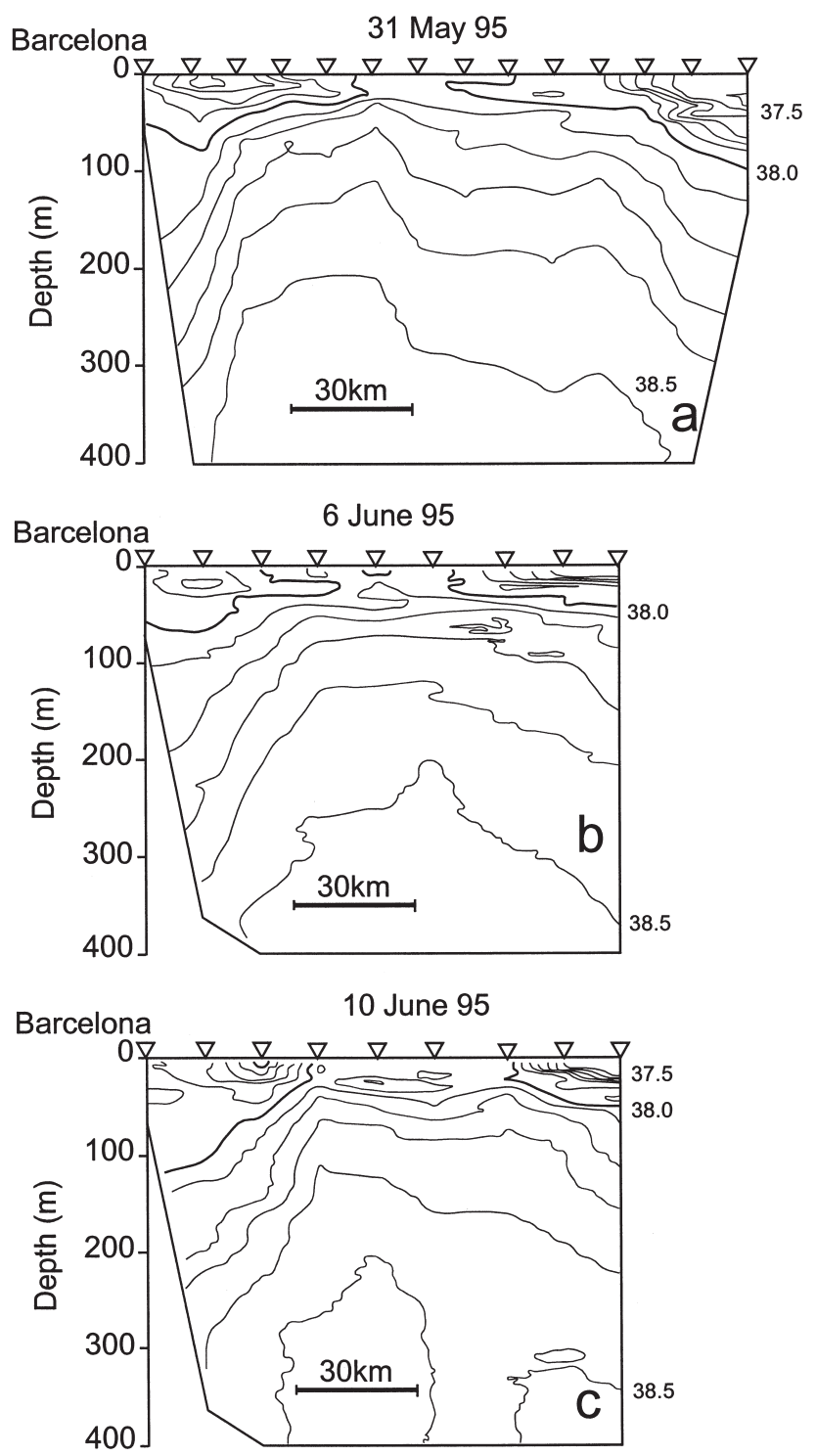

FIG. 3. - Vertical salinity sections along the transect sampled on a) 31 May 1995, b) 6 June 1995, and c) 10 June 1995 (see Fig. 1). 

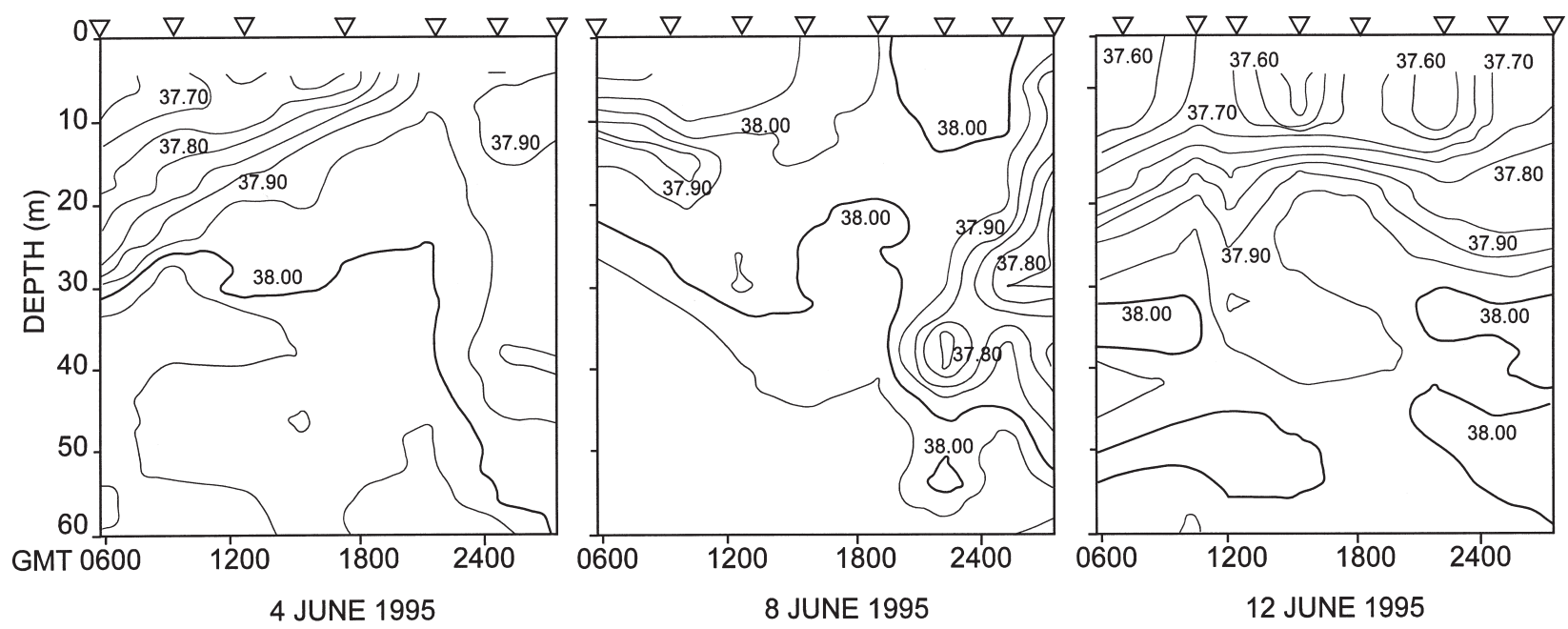

FIG. 4. - Varimed ' 95 survey: vertical distributions vs time for salinity at the 24-h sampling station over the slope (Figure 1 ) on a) 4 June 1995, b) 8 June 1995, and c) 12 June 1995.

shows spatial fluctuations (Fig. 2a), and the horizontal surface salinity distribution (Fig. $2 b$ ) reflects values lower than 37.5 in a strip about $15 \mathrm{~km}$ wide, looking like partly discontinuous lenses. This strip lies above the core of the geostrophic current.

In the vertical section off Barcelona done on 31 May the low salinity values did not reach depths greater than $25 \mathrm{~m}$ (Fig. 3a). In the replicate sampling of this same transect during the second cruise, low salinity water at the surface layer was again recorded in the frontal zone. In the sampling of 6 June the presence of low salinity water was less conspicuous and it was located close inshore (Fig. 3b). Conversely, in the sampling of 10 June, this water mass was better defined and was located farther offshore (Fig. 3c). In addition, low salinity water was also found in the series of samples carried out at the 24-hour fixed station over the slope. In the first cycle (4 June) the layer of low salinity water was present at the beginning and gradually receding to dissipate completely by the end of the cycle. This water was not present at all at the start of the second 24-hour cycle (8 June) but appeared at about $40 \mathrm{~m}$ by the end of the cycle. By the last visit to the station (12 June), the low salinity surface water formed a layer about $25 \mathrm{~m}$ deep that underwent small fluctuations during the day (Fig. 4).

\section{Surface Salinity}
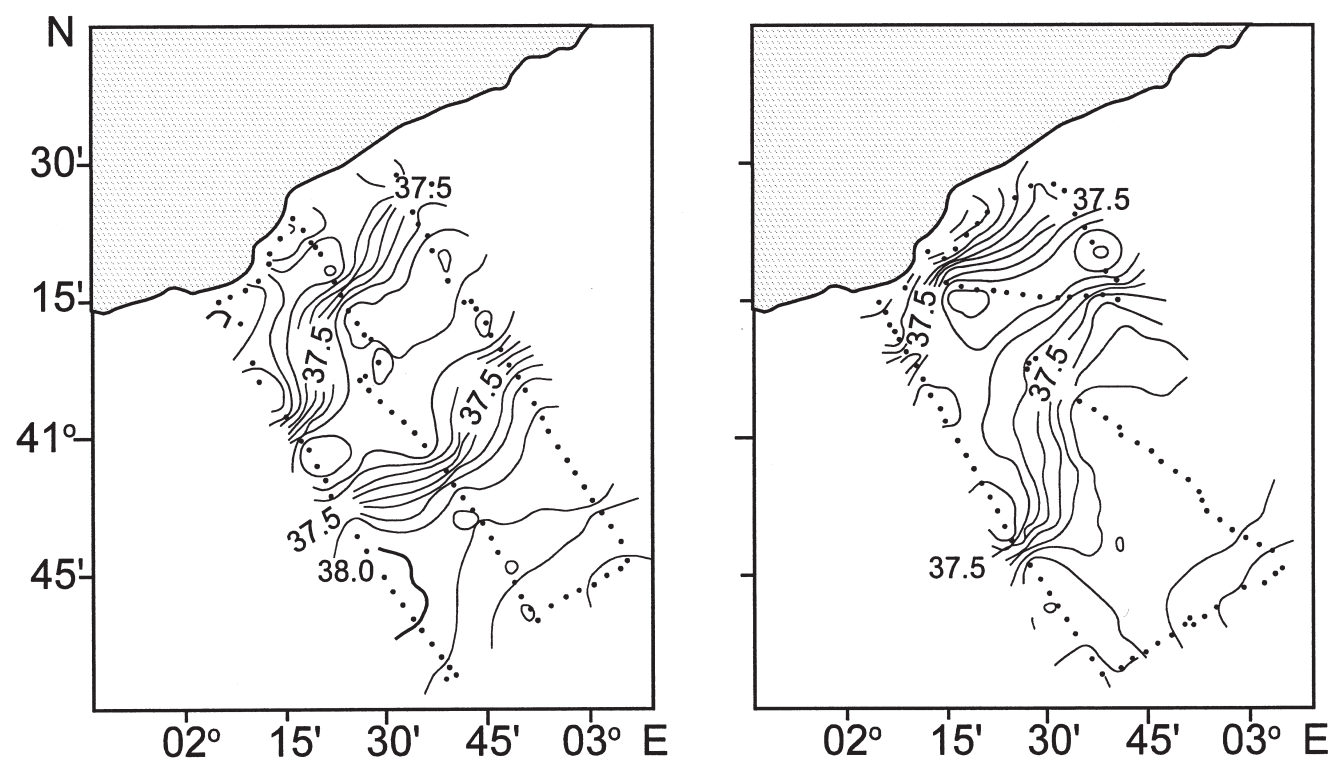

FIG. 5. - Fronts '95 survey: successive surface salinity distributions compiled from the continuous real-time data. 
The results of the third cruise again showed the presence of low salinity water at the surface in the shelf edge and slope region (Fig. 5). The strategy of this cruise made it possible to study for a few days the spatio-temporal evolution of the low salinity water, which moved in a southwesterly direction, following the predominant current. Furthermore, the continuous real-time surface measurements in Figure 5 are clearly indicative of the spatial continuity of what appeared as lenses in Figure $2 b$.

\section{Plankton}

The fluorescence profiles tended to display a deep maximum at a depth of between 35 and $70 \mathrm{~m}$ and very low levels at the surface, as is usual for this time of year. There were two exceptions to this rule: i) at stations located within the areas of less saline water, surface fluorescence values were relatively high, comparable to the deep maximum values; and ii) at certain inshore stations, particularly in the vicinity of Barcelona, surface fluorescence values were very high, about twice those of the typical deep chlorophyll maximum values or even higher. The latter may be due to local eutrophication from the harbour and urban sewage. On the third cruise, high surface fluorescence values (integrated from 0 to $30 \mathrm{~m}$ ) were associated with the low salinity and thus followed the same spatio-temporal distribution pattern (Fig. 6).

\section{Fluorescence}
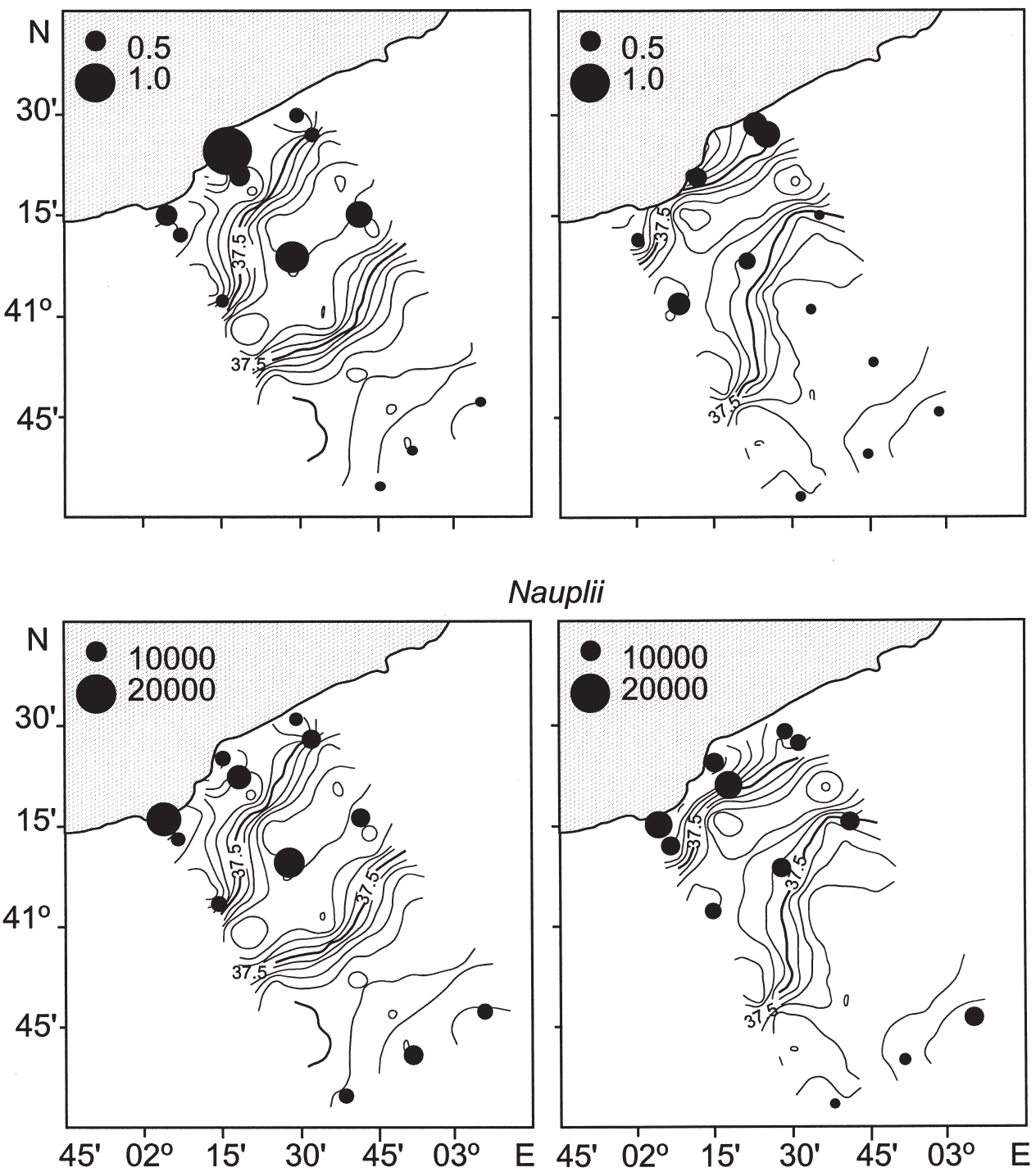

FIG. 6. - Fronts ' 95 survey: successive distributions for fluorescence, integrated from 0 to $30 \mathrm{~m}$ in depth, and nauplii abundance (individuals per $\mathrm{m}^{3}$ ), integrated from 0 to $40 \mathrm{~m}$ in depth. 


\section{Engraulis encrasicolus}
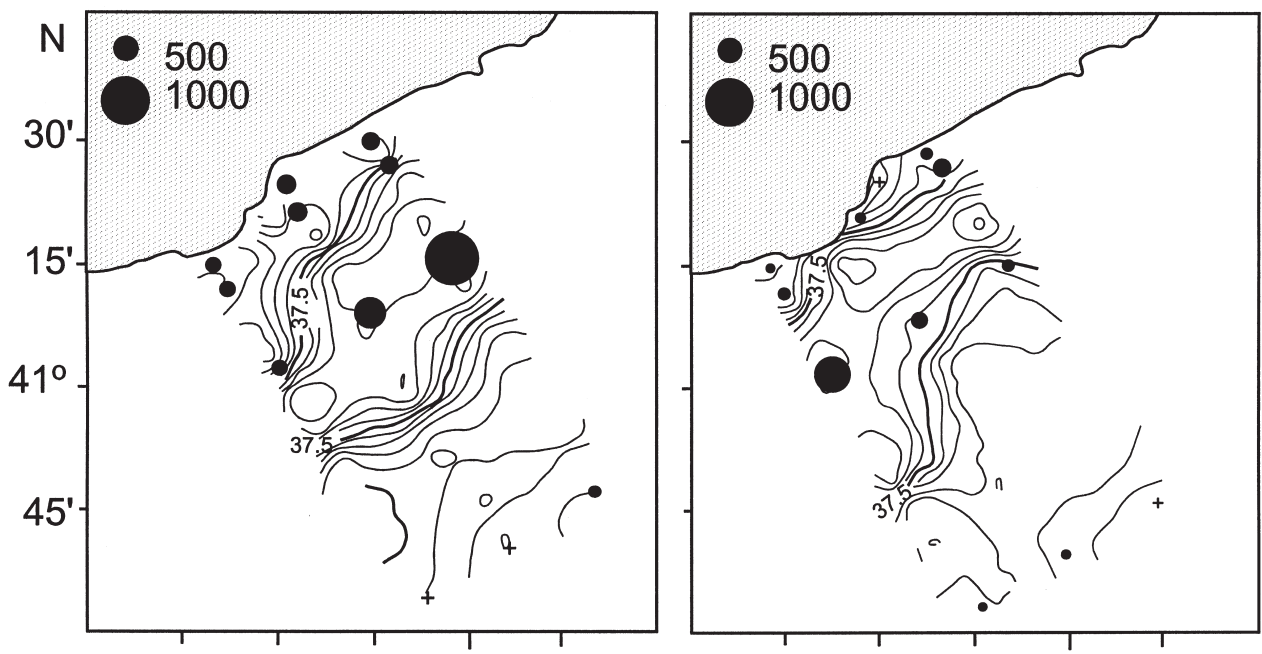

Hygophum benoiti
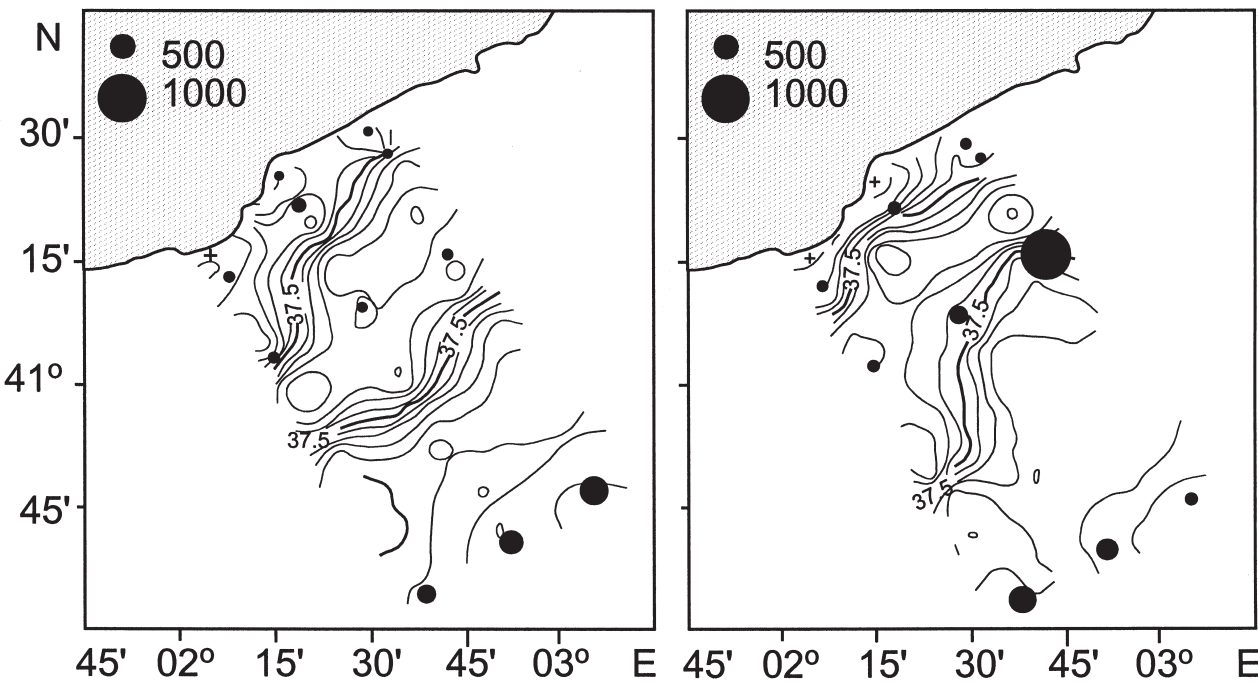

FIG. 7. - Fronts '95 survey: successive abundance distributions for the larvae of Engraulis encrasicolus and Hygophum benoiti (individuals per $10 \mathrm{~m}^{2}$ ).

Nauplius concentrations in the upper $40 \mathrm{~m}$ of the water column followed a similar distribution pattern to that recorded for the fluorescence values, with high inshore values over the shelf due to localized eutrophication effects. Over the slope, covered by low salinity waters, concentrations were similar to those over the shelf but appreciably lower than values at most oceanic stations (Fig. 6).

The most abundant fish larvae found throughout the study were larvae of the anchovy, Engraulis encrasicolus, and certain oceanic species, particularly Hygophum benoiti. Anchovy larvae accounted for $75 \%$ of the coastal species, equivalent to $18 \%$ of the total species collected. They were the only representative of coastal species at slope stations with low salinity surface waters. Larvae of the myctophid
Hygophum benoiti made up $30 \%$ of the oceanic species, equivalent to $22 \%$ of the total species collected. The relative abundance of the larvae of these two species varied between successive samplings during the third cruise. There was a clear association between anchovy larvae and low salinity (Fig. 7). On the first sampling circuit covering the grid, a centre of high larval densities (up to 1000 larvae per $10 \mathrm{~m}^{2}$ ) was recorded at the slope stations on the central and eastern transects (salinities lower than 37.5), whereas concentrations at the rest of the stations did not exceed 150 larvae per $10 \mathrm{~m}^{2}$. On the next circuit three days later, the larval distribution shifted in a southwesterly direction following the displacement of the low salinity water, with maximum concentrations at the slope station on the western transect (Fig. 7). 

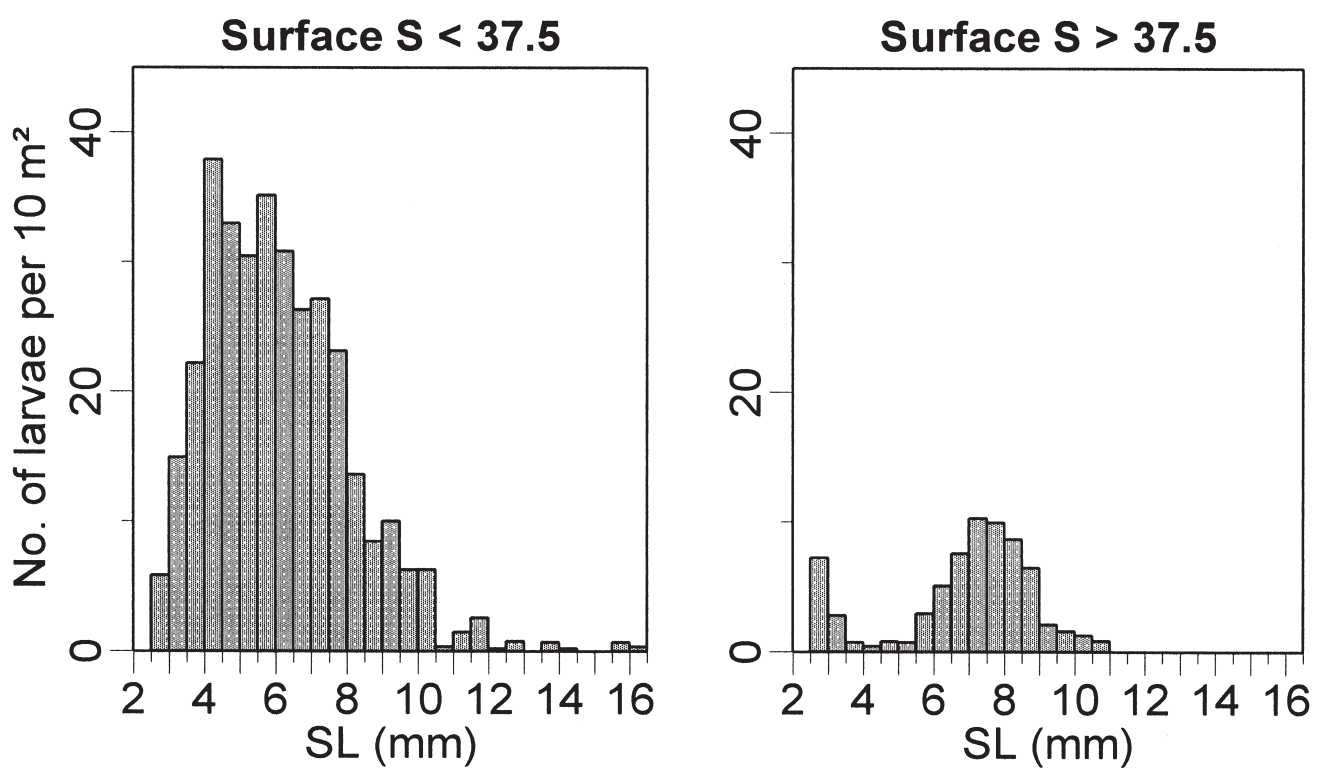

FIG. 8. - Fronts '95 survey: Size frequencies for the larvae of Engraulis encrasicolus at stations with surface salinity lower and higher than 37.5.

Larval sizes collected at the stations with surface salinity lower than 37.5 ranged between 2.5 and 16 $\mathrm{mm}$ SL. The size frequency distributions did not exhibit any well-defined modal size class, the classes between 4 and $7 \mathrm{~mm}$ being the most abundant. The size distribution of the few larvae collected at the stations with typical surface salinity values (higher than 37.5) displayed a bimodal structure, with peaks for size classes $2.5 \mathrm{~mm}$ (recently hatched larvae) and $7 \mathrm{~mm}$ (Fig. 8).

The larvae of the myctophid Hygophum benoiti were mainly located at all the oceanic stations. At the slope stations, the presence of these larvae was low over the first circuit, while on the second circuit its presence was only high at the slope station lying on the eastern transect, just where the low salinity water had receded from the surface (Fig. 7).

\section{DISCUSSION}

The presence of $C I W$ at surface in the vicinity of the slope region off the Catalan coast is commonly found by the end of spring (e.g. Tintoré et al., 1990). The $C I W$ found at surface in the present study is located where geostrophic current peaks (Fig. 2), thus suggesting that it was transported by the surface current. Comparing the distributions obtained on two successive circuits on the third cruise (Fig. 5), the strip of $C I W$ had moved southwest at the speed of the current, $25 \mathrm{~km}$ per day (equivalent to the 25 $30 \mathrm{~cm} \mathrm{~s}^{-1}$ calculated for the geostrophic surface cur- rent), which agrees with other observations at the same time of the year (Salat, 1995). The variable course of the strip of $C I W$ located over the shelfslope front deserves some special consideration. In previous studies (Alvarez et al., 1996; Estrada et al., 1998) successive observations had revealed shifts in the position of the shelf-slope front. However, the available information in those cases was insufficient to determine whether the movement was periodic. In the present study, comparing the vertical salinity sections constructed from successive visits to a transect off Barcelona (Fig. 3), the offshore distance of the centre of the strip ranges between 18 and $38 \mathrm{~km}$ : $28 \mathrm{~km}$ on 31 May, $18 \mathrm{~km}$ on 6 June, and $38 \mathrm{~km}$ on 10 June. This suggests that the alternation between more and less saline surface water was caused by an horizontal oscillation in the shelf-slope front with a period of about eight days and an amplitude close to $10 \mathrm{~km}$. Consequently, the fixed station on the slope was not always located within the $C I W$ strip: it was at the centre of the strip during the maximum offshore frontal displacement. Furthermore, the successive 24-hour sampling cycles carried out at the same station revealed that the episodes in which $C I W$ were present (Fig. 4) did not last more than two days. Since the width of the strip was about $15 \mathrm{~km}$ and the time observed to elapse between the maximum and minimum offshore displacements of the oscillation was four days, it turns out that the slope station should be under the influence of $C I W$ for about two-three days and then free of the influence of that water for five or six days, as was indeed 
shown by the observations. The distribution of $C I W$ appears to have followed the pattern of the general current associated with the front, but because of its oscillatory movement, oceanic water intruded towards the shelf in pulses.

Anchovy larvae were highly abundant in the strip of $C I W$ located over the slope. The abundance of larvae of the oceanic species Hygophum benoiti increased in the region of the slope when the oceanic water mass approached the shelf break as a result of oscillations in the front. Thus, the presence of these species is to some extent indicative of the position of the shelf-slope front with respect to the slope.

The size frequency distributions of the anchovy larvae (Fig. 8) are not indicative of the decreasing abundance from smaller to larger size classes that tends to characterise localised, stationary spawning. Instead, the maximum abundance values were for size classes between 4 and $7.5 \mathrm{~mm}$, indicating that the sampled population must have been spawned some four to ten days earlier (assuming a growth rate of $0.5 \mathrm{~mm} \mathrm{~d}^{-1}$ after García and Palomera, 1996). This size frequency structure reveals that the larvae were not only located in the strip of $C I W$ but that their development had actually taken place within these waters and that they had been carried along by the current. Bearing in mind the observed current velocity $\left(25 \mathrm{~km} \mathrm{~d}^{-1}\right)$, the larvae collected must have been spawned between 100 and $250 \mathrm{~km}$ upstream, that is, in the Gulf of Lions or just south of the Gulf. Furthermore, the paucity of fish larvae measuring under $4 \mathrm{~mm}$ suggests that local spawning, in front of Barcelona, must be very low. As a result most of the larvae located in that area must have been transported there by the current. These findings agree with the abundance of adults in the Gulf of Lions and the scarcity of adults off Barcelona reported by Pertierra and Lleonart (1996) and Abad et al. (1998). This would also account for the high concentrations of juveniles recorded by these last authors off Barcelona.

Previous studies carried out in the Catalan Sea had already revealed that the main spawning areas for anchovy are located in the vicinity of the mouths of the two largest rivers in the region, the Rhône and the Ebro rivers (Palomera and Sabatés, 1990; Palomera, 1992; García and Palomera, 1996). The fact that peak spawning intensity takes place when conditions are most conducive to the presence of low-salinity surface waters $(C I W)$ attests to that preference. In the Adriatic other researchers have also reported preferential spawning by anchovies in the region influenced by run-off from the Po River (Coombs et al., 1997). Anchovy spawning has also been related to the presence of low-salinity waters from nearby rivers in the North Atlantic and in areas like the southern Bay of Biscay (e.g. Motos et al., 1996). On the whole, all these workers have concluded that the persistence of enrichment mechanisms in the surface layer is the underlying cause for that association. In other geographic areas, numerous studies have shown the spatio-temporal connection between spawning by pelagic fish species and the enhanced plankton production associated with hydrographic phenomena (e.g. Brewer, 1978; Kiorboe, 1991; Fletcher et al., 1994; Bakun, 1996; Peebles et al., 1996). It has been argued that the high productivity may afford adequate adult feeding (Blaxter and Hunter, 1982), thereby increasing spawning intensity and affording a suitable habitat for larval development and survival (Castro and Cowen, 1991; Peebles et al., 1996).

Though the Mediterranean is an oligotrophic sea, it nonetheless presents a series of mechanisms enhancing fertility at certain times of the year or in connection with more or less localised hydrographic structures (Estrada et al., 1993; Estrada, 1996). During the anchovy spawning season, surface fluorescence levels in the upper $30 \mathrm{~m}$ are very low, indeed practically negligible, except at those locations where there have been recent inputs of continental water or where active vertical mixing is in operation (very uncommon at that time of year). All primary production is generally confined to a depth range between 40 and $100 \mathrm{~m}$, where it gives rise to what is known as the deep chlorophyll maximum (Estrada, 1985). The observations recorded during the present study have confirmed that tendency, with a good correlation between relative surface fluorescence maxima and the presence of $C I W$, indicating that these waters are more productive at the primary production level (Figs. 5 and 6). Cruzado and Velásquez (1990) reported that waters under the influence of continental run-off from the Rhône on the shelf in the Gulf of Lions had higher nutrient and phytoplankton concentrations than adjacent oceanic waters. Furthermore, high microzooplankton (Tudela and Palomera, 1995) and copepod (Razouls and Kouwenberg, 1993) densities have been recorded in the Gulf of Lions, along with an increase in zooplankton biomass and feeding activity in the outflow plume of the Rhône River (Pagano et al., 1993). Since anchovy larvae feed mainly on juvenile copepod stages (Tudela and Palomera, 1995) and 
larvae in the initial developmental stages may also feed on phytoplankton (Lasker, 1975), conditions in the waters from the Gulf of Lions should be favourable to anchovy larval development. This agrees with the findings made by García et al. (1998) regarding the growth and feeding condition of anchovy larvae. The effect of plumes of continental fresh water on larval survival has been intensively studied near the mouth of the Mississippi River. According to Govoni and Chester (1990) and Grimes and Finucane (1991), the plume habitat appears to afford conditions favourable to the growth and survival of fish larvae.

It should be noted that in the NW Mediterranean at the end of spring, a time of peak anchovy spawning (Palomera, 1992), the abundance of anchovy larvae is an order of magnitude higher than the abundance of the larvae of other fish species spawning during that same period (Sabatés, 1990a). In addition, anchovy larvae are concentrated in the upper levels of the water column (Palomera, 1991; Olivar and Sabatés, 1997). In turn, these high larval concentrations require dense patches of appropriate food. It is also pertinent to note Hunter's (1972) observations concerning the low success rates of prey capture by first-feeding anchovy larvae, which indicate that high prey densities are needed at the time of first feeding to offset the low success rates. In the present study, fluorescence and copepod nauplii concentration values recorded within $C I W$ suggest that by the end of spring the habitat in these waters experiences conditions favourable to the growth and development of surface-dwelling larvae like those of anchovy. The predominance of anchovy as a species, and the extremely high abundance of anchovy larvae during late spring, suggests that the species is able to take advantage of the situation.

It might be asked why other fish species spawning during that same period do not exploit the relatively high production associated with the continental run-off. The ability of anchovy larvae to live in habitats with varying salinity levels has been well documented (e.g. Demir, 1965), while for larvae of other species the trophic advantage that may be achieved by dwelling in those more productive waters is offset by the drawback of having to survive at lower than usual salinity levels. This situation was observed off the Catalan coast by Sabatés (1990b), who found that anchovy were the only species present in areas with extremely low salinity values. In addition, the larvae are carried far away from the area where they are spawned by advection. Transport away from the area of spawning has been reported in clupeoid species in other geographical areas (e.g. Shelton and Hutchings, 1982). However, since anchovy is a pelagic species, advection does not appear to pose any particular disadvantage to that species. In contrast, transport away from the spawning areas could pose a serious predicament for future recruitment by the larvae of inshore benthic species, whose adults are bottom-dwellers. In fact, Sabatés (1990a) found that the larval distributions for the benthic species were closely correlated to bottom type along the coast of Catalan coast.

In summary, by the end of spring, the peak spawning period for anchovy, resources in the surface layers where anchovy larvae dwell are limited by the scarce mechanisms for enrichment of surface waters at that time of year. As a result, anchovy exploit the presence of inputs of continental waters, the main mechanism of primary production at the surface in the Western Mediterranean during that period. The present study shows that anchovy larvae develop chiefly within those waters, which are carried along by the main current flowing along the edge of the shelf. Although the larvae are advected away from the spawning area, they remain together in a favourable habitat for their growth and development during the displacement.

\section{ACKNOWLEDGEMENTS}

We greatly appreciate the assistance of the crews of the R/V García del Cid and the BIO Hespérides and all our colleagues onboard during the cruises mentioned in this paper. We thank P. Philippe for her assistance in the laboratory. We also thank M. Estrada and I. Palomera for useful criticisms. This work was supported by grants AMB94-1019 and AMB94-0853 from CICYT and MAS3-CT96-0051 from the EU.

\section{REFERENCES}

Abad, R., M. Miquel, M. Iglesias and F. Álvarez. - 1998. Acoustic estimation of abundance and distribution of anchovy in the NW Mediterranean. Sci. Mar., 62: 37-43.

Albérola, C., C. Millot and J. Font. - 1995. On the seasonal and mesoscale variabilities of the Northern Current during the PRIMO-0 experiment in the western Mediterranean sea. Oceanol. Acta, 18: 163-192.

Álvarez, A., J. Tintoré and A. Sabatés. - 1996. Flow modification and shelf-slope exchange induced by a submarine canyon off the northeast Spanish coast. J. Geophys. Res., 101: 12043-12055.

Bakun, A. - 1996. Patterns in the ocean, ocean processes and 
marine population dynamics. California Sea Grant/CIB.

Blaxter, J.H.S. and J.R. Hunter. - 1982. The biology of clupeoid fishes. Adv. Mar. Biol., 20: 1-223.

Brewer, G.D. - 1978. Reproduction and spawning of the northern anchovy, Engraulis mordax, in San Pedro Bay, California. Calif. Fish. Game, 63: 175-184.

Castellón, A., J. Salat and M. Masó. - 1985. Some observations on Rhône fresh water plume in the Catalan Coast. ). Rapp. P-V, Commn. Int. Explor. Scient. Mer Méditerr., 29: 3.

Castellón, A., J. Font and E. García-Ladona. - 1990. The LiguroProvençal-Catalan current (NW Mediterranean) observed by Doppler profiling in the Balearic sea. Sci. Mar., 54: 269-276.

Castro, L.R. and R.K. Cowen. - 1991. Environmental factors effecting the early life history of bay anchovy Anchoa mitchilli in Great South Bay, New York. Mar. Ecol. Prog. Ser., 76: 235-247.

Coombs, S., O. Giovanardi, D. Conway, L. Manzueto, N. Halliday and C. Barrett. - 1997. The distribution of eggs and larvae of anchovy (Engraulis encrasicolus) in relation to hydrography and food availability in the outflow of the River Po. Acta Adriat., 38: 33-47.

Cruzado, A. and Z.R.Velásquez. - 1990. Nutrients and phytoplankton in the Gulf of Lions, northwestern Mediterranean. Cont. Shelf Res., 10: 931-942.

Demir, M. - 1965. Synopsis of biological data on anchovy Engraulis encrasicolus (Linnaeus, 1758) (Mediterranean and adjacent seas). FAO Fish. Synop., 26: 1-42.

Estrada, M. - 1985. Deep phytoplankton and chorophyll maxima in the Western Mediterranean. In: M. Moraitou-Apostolopoulou and V. Kortsis (eds.), Mediterranean Marine Ecosystems, Plenum Press, New York.

Estrada, M. 1996. Primary production in the northwestern Mediterranean. Sci. Mar., 60 (Supl.2): 55-64.

Estrada, M. and J. Salat. - 1989. Phytoplankton assemblages of deep and surface water layers in a Mediterranean frontal zone. In: J.D. Ros (ed.), Topics in Marine Biology, Sci. Mar., 53: 203-214

Estrada, M., C. Marrasé, M. Latasa, E. Berdalet, M Delgado and T. Riera. - 1993. Variability of deep chorophyll maximum characteristics in the Northwestern Mediterranean. Mar. Ecol. Prog. Ser., 92: 289-300.

Estrada, M., R.A. Varela, J. Salat, A. Cruzado and E. Arias. - 1999 Spatial and temporal variability of the winter phytoplankton distribution across the Catalan and North Balearic fronts (NW Mediterranean). J. Plankton Res., 21: 1-20.

Fletcher, W.J., R.J. Tregonning and G.J. Sant. - 1994. Interseasonal variation in the transport of pilchard eggs and larvae off southern Western Australia. Mar. Ecol. Prog. Ser., 111: 209-224.

Font, J., J. Salat, and J. Tintoré. - 1988. Permanent features of the circulation in the Catalan sea. In: H.J. Minas and P. Nival (eds.), Pelagic Mediterranean oceanography, Oceanol. Acta, 9: 51-57.

Font, J., E. García-Ladona and E.G. Górriz. - 1995. The seasonality of mesoscale motion in the Northern Current of the western Mediterranean: several years of evidence. Oceanol. Acta, 18: 207-219.

García, A. and I. Palomera. - 1996. Anchovy early life history and its relation to its surrounding environment in the Western Mediterranean basin. Sci. Mar., 60 (Supl.2): 155-166.

García, A., D. Cortés and T. Ramírez. - 1998. Daily larval growth and RNA and DNA content of the NW Mediterranean anchovy Engraulis encrasicolus and their relations to the environment. Mar. Ecol. Prog. Ser., 166: 237-245.

Govoni, J.J. and A.J. Chester. - 1990. Diet composition of larval Leistomus xanthurus in and about the Mississippi River plume. J. Plankton Res. 12: 819-830.

Grimes, C.B. and J.H. Finucane. - 1991. Spatial distribution and abundance of larval and juvenile fish, chlorophyll and macrozooplankton around Mississippi River discharge plume, and the role of the plume in fish recruitment. Mar. Ecol. Prog. Ser., 75: 109-119.

Hunter, J.R. - 1972. Swimming and feeding behavior of larval anchovy, Engraulis mordax. Fish. Bull. U.S., 70: 821-848.

Kiorboe, T. - 1991. Pelagic fisheries and spatio-temporal variability in zooplankton productivity. Bull. Plank. Soc. Jpn., Spec. Vol., 229-249.
Lasker, R. - 1975. Field criteria for survival of anchovy larvae: the relation between inshore chlorophyll maximum layers and successsful first feeding. Fish. Bull. US, 73: 453-462.

Masó, M., A. Sabatés and M.P. Olivar. - 1998. Short-term physical and biological variability in the shelf-slope region of the NW Mediterranean during the spring transition period. Cont. Shelf Res., 18: 661-675.

Millot, C. - 1990. The Gulf of Lions' hydrodynamics. Cont. Shelf Res., 10: 885-894.

Motos, L., A. Uriarte and V. Valencia. - 1996. The spawning environment of the Bay of Biscay anchovy (Engraulis encrasicolus L.). Sci. Mar., 60 (Supl.2): 117-140.

Olivar, M.P. and A. Sabatés. - 1997. Vertical distribution of fish larvae in the NW Mediterranean Sea in spring. Mar. Biol., 129: 289-300.

Olivar, M.P., A. Sabatés, P. Abelló and M. García. - 1998. Transitory hydrographic structures and distribution of fish larvae and neustonic crustaceans in the north-western Mediterranean. Oceanol. Acta, 21: 95-104.

Pagano, M., R. Gaudy, D. Thibault and F. Lochet. - 1993. Vertical migrations and feeding rhythms of mesozooplanktonic organisms in the Rhône river plume area (North-west Mediterranean Sea). Est. Coast. Shelf Sci., 37: 251-269

Palomera, I. - 1991. Vertical distribution of eggs and larvae of Engraulis encrasicolus, in stratified waters of the Western Mediterranean. Mar. Biol., 111: 37-44.

Palomera, I. - 1992. Spawning of anchovy Engraulis encrasicolus, in the North-Western Mediterranean relative to hydrographic features in the region. Mar. Ecol. Prog. Ser., 79: 215-223.

Palomera, I. and A. Sabatés. - 1990. Co-occurrence of Engraulis encrasicolus eggs and larvae in the North-Western Mediterranean. Sci. Mar., 54: 61-67.

Peebles, E.B., Hall and J.R. Tolley. - 1996. Egg production by the bay anchovy Anchoa mitchilli in relation to adult and larval prey fields. Mar. Ecol. Prog. Ser., 131: 61-73.

Pertierra, J.P. and J. Lleonart. - 1996. NW Mediterranean anchovy fisheries. Sci. Mar., 60 (Supl. 2): 257-267.

Pinot, JM., J. Tintoré and D. Gomis. - 1994. Quasi-synoptic mesoscale variability in the Balearic Sea. Deep-Sea Res., 41: $897-914$.

Razouls, C. and J.H.M. Kouwenberg. - 1993. Spatial distribution and seasonal variation of mesozooplankton biomass in the Gulf of Lions (northwestern Mediterranean). Oceanol. Acta 16: $393-401$.

Sabatés, A. - 1990a. Distribution pattern of larval fish populations in the northwestern Mediterranean. Mar. Ecol. Prog. Ser., 59: $75-82$

Sabatés, A. - 1990b. Changes in the heterogeneity of mesoscale distribution patterns of larval fish associated with a shallow coastal haline front. Estuar. Coast. Shelf Sci., 30: 131-140

Sabatés, A. and M. Masó. - 1992. Unusual larval fish distribution pattern in a coastal zone of the western Mediterranean. Limnol. Oceanogr., 37: 1252-1260.

Sabatés, A. and M.P. Olivar. - 1996. Variation of larval fish distributions associated with variability in the location of a shelfslope front. Mar. Ecol. Prog. Ser., 135: 11-20.

Salat, J. - 1995. The interaction between the Catalan and Balearic currents in the southern Catalan Sea. Oceanol. Acta, 18: 227234.

Salat, J., A. Cruzado and M. Panouse. - 1990. Contribution of the Rhône river discharges to the dynamics of the Gulf of Lions in Autumn 1986. Rapp. P-V, Commn. Int. Explor. Scient. Mer Méditerr., 32: 168

Shelton, P.A. and L. Hutchings. - 1982. Transport of anchovy Engraulis capensis Gilchrist eggs and early larvae by a frontal jet current. J. Cons. Int. Explor. Mer, 40: 185-198.

Tintoré, J., D.P. Wang and P.E. La Violette. - 1990. Eddies and Thermohaline Intrusions of the Shelf/Slope Front off the Northeast Spanish Coast. J. Geophys. Res., 95: 1627-1633.

Tudela, S. and I. Palomera. - 1995. Microzooplankton and feeding of anchovy larvae in the northwestern Mediterranean. Rapp. PV, Commn. Int. Explor. Scient. Mer Méditerr., 34: 259.

Wang, D.P., M.E.C. Vieira, J. Salat, J. Tintoré, P.E. La Violette. 1988. A shelf/slope frontal filament off the northeast Spanish coast. J. Mar. Res., 46: 321-332. 
